\title{
The first Cenozoic Equisetum from New Zealand ${ }^{\text {is }}$
}

\author{
Mike Pole ${ }^{\mathrm{a}}$, Stephen McLoughlin ${ }^{\mathrm{b}, *}$ \\ ${ }^{a}$ Queensland Herbarium, Brisbane Botanic Gardens Mt Coot-tha, Mt Coot-tha Rd, Toowong QLD 4066, Australia \\ ${ }^{\mathrm{b}}$ Department of Palaeobiology, Swedish Museum of Natural History, Box 50007, 10405 Stockholm, Sweden
}

\section{A R T I C L E I N F O}

\section{Article history:}

Received 27 December 2016

Accepted 20 April 2017

Available online 3 May 2017

\section{Keywords:}

Sphenophyta

Equisetales

Australasia

Extinction

Miocene

Paleoclimate

\begin{abstract}
A B S T R A C T
Equisetum is described for the first time from Cenozoic deposits of New Zealand. The fossils derive from two early to earliest middle Miocene assemblages in South Island, New Zealand. The fossils are ascribed tentatively to subgenus Equisetum based on their possession of whorled branch scars, but they cannot be assigned with confidence to a formal species. The decline of equisetaleans, otherwise unknown from the Cenozoic of the New Zealand-Australian-Antarctic domain, was possibly a consequence of severe environmental changes - particularly, abrupt shifts in the temperature and soil moisture regime experienced by this region in the Neogene, coupled with competition from opportunistic angiosperms.
\end{abstract} (c) 2017 Elsevier Masson SAS. All rights reserved.

\section{Introduction}

Equisetum is an almost cosmopolitan genus of about 15 extant species and several extinct species (Hauke, 1963, 1978). It includes the only extant representatives of Equisetopsida - traditionally placed in Division Equisetophyta Scott, 1900, Calamophyta Smith, 1955, Sphenophyta Benson, 1957, or Arthrophyta Bold et al., 1987, and more recently considered a basal member of, or sister group to the ferns based on both morphological and molecular studies (Kenrick and Crane, 1997; Pryer et al., 2001, 2004; Des Marais et al., 2003; Guillon, 2004, 2007; Smith et al., 2006). New Zealand, Australia and Antarctica have a natural absence of extant Equisetum (commonly known as 'horsetails' or 'scouring rushes'). The absence of indigenous Equisetum from New Zealand and Australia is curious, because these regions host a rich Paleozoic and Mesozoic fossil record of equisetaleans, and representatives of the extant genus thrive in these regions today as exotic weeds (Clifford and Constantine, 1980; Brownsie and Perrie, 2015).

Today Equisetum is the sole surviving genus of a once diverse plant group (generally called sphenopsids or equisetopsids) that appeared in the Devonian (Taylor et al., 2009). Equisetopsid fossils are known from all the major Southern Hemisphere landmasses with a record extending back to at least the Carboniferous (Morris, 1985; Gutiérrez, 1995). The group maintained a high diversity,

\footnotetext{
Corresponding editor: Marc Philippe.

* Corresponding author.

E-mail address: steve.mcloughlin@nrm.se (S. McLoughlin).
}

including some arborescent forms (Rössler and Noll, 2002, 2006) through the late Paleozoic (Boureau, 1964), was represented by a reduced diversity of mainly herbaceous forms through the early and middle Mesozoic, then declined through the Cretaceous, apparently concomitant with the diversification of angiosperms (Coiffard et al., 2007). Late Mesozoic and Cenozoic fossil Equisetum are assigned to Equisetites by some authors, although typically this is an expression of philosophy - there are essentially no morphological differences between these genera (Harris, 1961; Gould, 1968) and we presume that they belong to the same monophyletic group. In this paper, we use Equisetum for fossils.

Based on molecular dating, Des Marais et al. (2003) proposed that the crown group of Equisetum diverged about $64.8 \pm 12.7$ million years ago (early Paleocene). However, the stem lineage is much older; several mid-Mesozoic taxa including the Early Jurassic Equisetum dimorphum Elgorriaga et al. (2015) from Patagonia, the Middle Jurassic Equisetum laterale Gould (1968) from Australia, and the Late Jurassic Equisetum thermale Channing et al. (2011) from Patagonia are among the oldest confirmed records of the genus.

In New Zealand, equisetopsids have been reported from the Permian (Equisetites; McQueen, 1954), Triassic (Neocalamites; Retallack, 1980, 1985), Jurassic (Equisetites; Arber, 1917; Edwards, 1934), and Cretaceous (Equisetum; Daniel, 1989; Daniel et al., 1990; Parrish et al., 1998). It is probable that von Ettingshausen's (1891) slender jointed stems assigned to Casuarina deleta Ett. from Shag Point (Campanian), and Bambusites australis Ett. and Casuarinites cretaceus Ett. from Pakawau (late Campanian-Maastrichtian) constitute the youngest known Equisetum fossils from 
New Zealand thus far, since at least some of those specimens represent segmented axes that are too broad for typical photosynthetic twigs of Casuarina; dispersed pollen of Casuarinaceae first appears in New Zealand only in the Paleocene (Mildenhall, 1980; Macphail et al., 1994).

The Australian equisetopsid record extends back further, at least to the Carboniferous (Retallack, 1999) and is more diverse, with many genera known from Permian and Triassic deposits (e.g., Rigby, 1966; McLoughlin, 1992a, 1992b; Holmes, 2001). The group persisted through the Jurassic and Early Cretaceous in Australia with moderate representation of herbaceous forms (Gould, 1968; Douglas, 1973; McLoughlin and Drinnan, 1995; McLoughlin et al., 2000, 2002; Turner et al., 2009) but declined to just a single known occurrence in the Cenomanian (McLoughlin et al., 2010). No records are known from the Cenozoic. In Antarctica, diverse equisetopsids are known from Permian-Jurassic strata (Rigby, 1969; Gee, 1989; Osborn et al., 2000; Rees and Cleal, 2004; Bomfleur et al., 2013) and persisted until at least the late Albian in the Alexander Island region (Falcon-Lang et al., 2001). Thus, the previous youngest records of equisetopsids from Australia, Antarctica and New Zealand are all of mid- to Late Cretaceous age.

Here we describe Equisetum remains from two early to earliest middle Miocene fossil assemblages of New Zealand. We also assess the potential causes of equisetalean decline in southeastern Gondwana during the Late Cretaceous and Cenozoic.

\section{Geological setting}

Fossil Equisetum specimens were recovered from two localities in New Zealand. One is near the village of Bannockburn, central Otago, South Island. The material was collected in 1990, and derives from a layer at about $25 \mathrm{~m}$ on the 'Bannockburn Section' figured by Pole (1993a: fig. 9; coordinates: New Zealand Transverse Mercator 1298664, 5000792; Fig. 1(1, 3)). The specimens form a monospecific assemblage preserved in massive, soft, pale, clay-rich mudstone that forms part of the fluvial Dunstan Formation of the Manuherikia Group (Douglas, 1986). The Bannockburn Section broadly correlates with the Kawarau Section (Douglas, 1986) about $4 \mathrm{~km}$ away. Based on palynological content (Mildenhall and Pocknall, 1989), the Kawarau Section is regarded as Altonian at the base (lower to lowermost middle Miocene; Cooper, 2004), but upper levels may range higher into the middle Miocene. Given that they are from relatively low in the Bannockburn Section, the Equisetum fossils described here are likely to be Altonian (upper Burdigalian to lowermost Langhian).

The second locality is from the banks of the Buller River, about $200 \mathrm{~m}$ north of Nuggety Creek, and nearly $10 \mathrm{~km}$ northeast of the town of Murchison in northwestern South Island (coordinates: New Zealand Transverse Mercator 1550440, 5379230; Fig. 1(1, 2)). Leaf macrofossils from this locality have been described previously by Holden (1982a, 1982b). The fossiliferous mudrock is darker, more fissile and more lithified relative to that at Bannockburn. These strata are included in the Longford Formation, which was deposited in the Murchison Basin (Fyfe, 1968; Lihou, 1993). Fossil spore-pollen recovery has been unsuccessful so far but, as the fluvial Longford Formation overlies the estuarine early Miocene (Altonian) Mangles Formation, the age of the former unit is inferred to be middle Miocene (Nathan et al., 1986). In the year 2000, fossil Equisetum and ferns were exposed on the bedding surfaces of large fallen blocks of mudstone on the edge of the Buller River. These are some 20-30 m topographically below a leaf bed that was probably the source of Holden's Nothofagus fossils. As the strata dip steeply, the Equisetum-bearing layer is stratigraphically close (within $10 \mathrm{~m}$ ) to the Nothofagus bed, but the exact relationship is not clear.

\section{Material and methods}

Numerous fossil Equisetum specimens are available from Bannockburn, consisting of external axis impressions and flattened

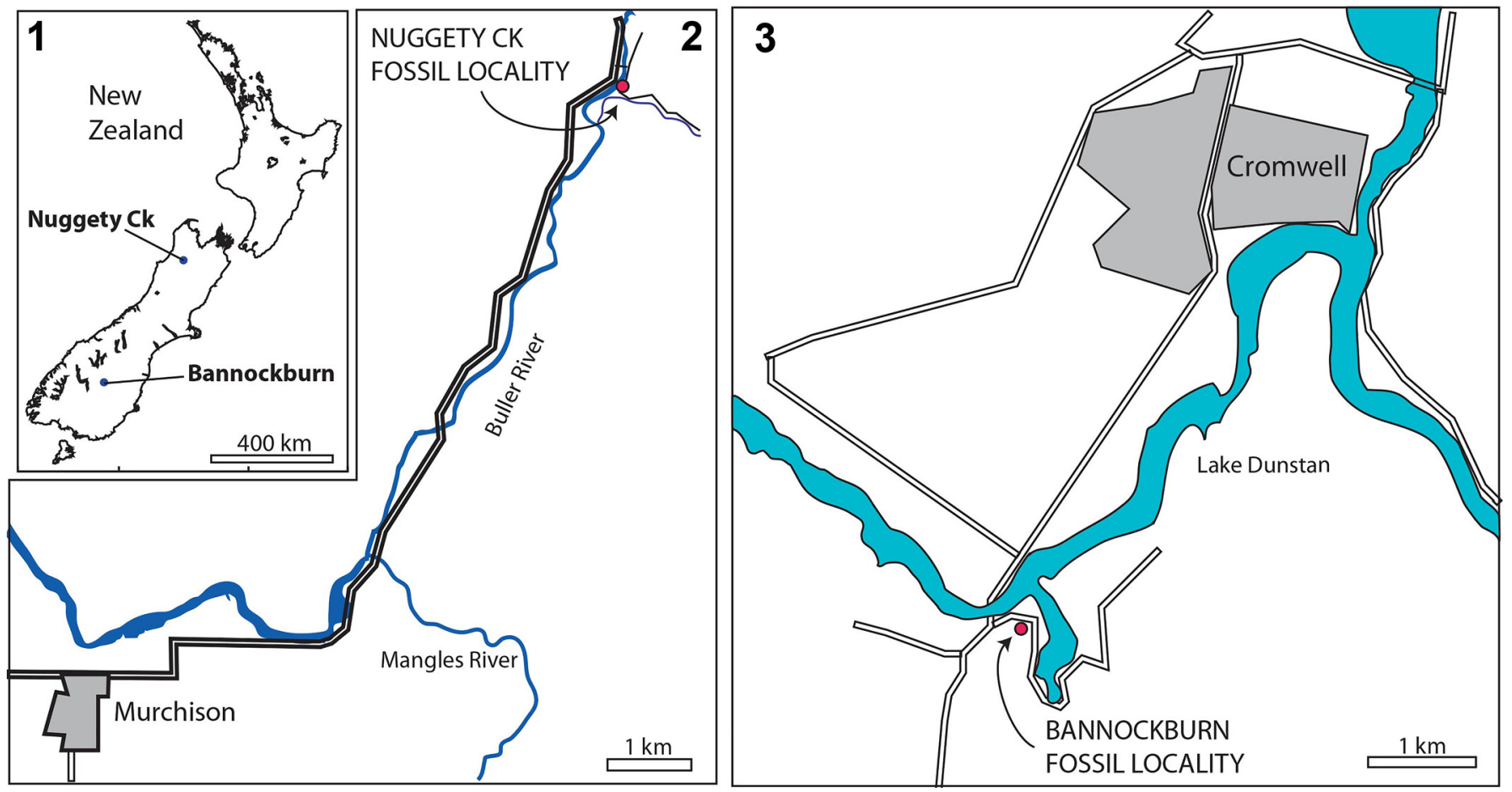

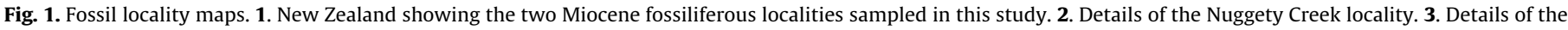
Bannockburn locality. 
pith casts in pale grey shale (of which five have been registered). Several specimens (three registered) were recovered from Nuggety Creek near Murchison, comprising coalified compressions and associated impressions in pale grey shale. Specimens were uncovered using a vibrating chisel and photographed in reflected light. Illustrated material is deposited in the collections of the Department of Geology, University of Auckland under the prefix 'LX'.

\section{Systematic paleobotany}

Division Pteridophyta Schimp. in K.A. Zittel, 1879-1890

Class Equisetopsida C. Agardh, 1825

Order Equisetales de Candolle. ex von Berchtold and Presl, 1820

Family Esuidetaceae Michx. ex de Candolle, 1804

Genus Equisetum von Linnaeus, 1753

Subgenus ?Equisetum von Linnaeus, 1753

Type species: Equisetum fluviatile von Linnaeus, 1753 (extant).

Equisetum $s p$.

Fig. 2

Material: Bannockburn: LX0833-LX0837; Murchison: LX0881, LX0882, LX2065.

Localities and stratigraphic units: Specimens from Bannockburn (central Otago, South Island, New Zealand) derive from the Dunstan Formation (early to earliest middle Miocene), Manuherikia Group. Specimens listed under the locality 'Murchison' derive from the Longford Formation (middle Miocene), Murchison Basin, at Buller River, about $200 \mathrm{~m}$ north of Nuggety Creek, $c a .10 \mathrm{~km}$ northeast of Murchison (northwestern South Island, New Zealand).

Description: Parallel-sided, jointed axes ca. 9-19 mm wide, preserved as pith casts (Fig. 2(1)), external impressions (Fig. 2(2, 3, 7-9)), and carbonaceous compressions (Fig. 2(4-6)). Both pith casts and stem surfaces bear longitudinal ridges and nodes $\mathrm{ca}$. $130 \mathrm{~mm}$ apart. Ridges are slightly more pronounced on pith casts than stem exteriors, in both cases bearing fine longitudinal striae. Nodes are marked by a ring of elliptical to ovate branch scars (5-15 evident across the exposed half of the axis), which are ca. $0.5-2 \mathrm{~mm}$ wide and $0.5-3.5 \mathrm{~mm}$ long. Remnants of a leaf sheath are evident on one specimen (Fig. 2(7)) as linear to narrowly triangular, apically pointed, longitudinally striate, basally fused lamina segments.

Remarks: In the context of Cenozoic floras, these axes are best referred to Equisetum based on their ribbed and jointed stems with leaf sheaths and branch scars located at the nodes. Of the two extant subgenera of Equisetum, subgenus Hippochaete tends to lack lateral branches and is distributed in both the Northern and Southern hemispheres, whereas representatives of subgenus Equisetum tend to be branched but are restricted mostly to the Northern Hemisphere (Hauke, 1990, 1993). Despite its Southern Hemisphere location, we tentatively assign the New Zealand fossils to subgenus Equisetum on the basis of their numerous branch scars preserved at the nodes, but confident assignment to subgenus or species must await the discovery of strobilar or stomatal characters.

Several of the stem impressions and pith cast surfaces bear roughly elliptical to circular stains or dimples (Fig. $2(1,2,7,8)$ ). Although similar-sized features on fossil equisetalean stems have been interpreted as insect oviposition scars in other studies (e.g., Beattie, 2007; Labandeira, 2013), the features on the New Zealand axes lack reaction tissue and are too inconsistent in shape, arrangement and position to represent arthropod damage scars. They probably represent diagenetic features.

The previous youngest (Late Cretaceous) examples of equisetaleans from Australasia are somewhat variable in size, quality and style of preservation but, collectively, they appear to encompass the dimensions and architectures of the New Zealand Miocene fossils. Daniel's (1989) Equisetum sp. from the Cenomanian Warder Formation of the middle Clarence Valley, South Island, New Zealand, is a branched rhizome with short, coarsely ribbed internodes. The specimens attributed by von Ettingshausen (1891) to Bambusites australis, Casuarinites cretaceus and Casuarina deleta from Shag Point (Campanian) and Pakawau (late Campanian-Maastrichtian), South Island, New Zealand, represent jointed and more finely ribbed rhizomes and subaerial axes (some with whorls of scale-like leaves) that range from $c a .1$ to $35 \mathrm{~mm}$ wide. Equisetites sp. of McLoughlin et al. (2010) from the Winton Formation (latest Albian-earliest Turonian; Tucker et al., 2013) of eastern Australia is represented by probable rhizome pith casts 12-22 mm wide with variable-length internodes, coarse longitudinal ridges, rings of small circular (?root) scars at the nodes, and associated nodal diaphragms with up to 28 tubercles around the rim.

All of the Australasian Cretaceous specimens lack sufficient characters for confident attribution to a formal species. Given the absence of diagnostic reproductive organs or cuticular features, and the limited macromorphological details available from the segmented axes, we also refrain from assigning the New Zealand Miocene specimens to a new or established species. Nevertheless, these new fossil records are important for deciphering the vegetation history of the landmasses that formerly constituted southeastern Gondwana.

\section{Discussion}

\subsection{Australasian refugium for Mesozoic plants}

Despite the rich paleobotanical heritage of the region, the new fossils are the only record of equisetaleans in New Zealand (and Australasia) from the past 70 million years. The $500 \mathrm{~km}$ separating the two Miocene localities suggests that Equisetum was widely distributed in the South Island at that time. The fossils also suggest that the current absence from New Zealand (as well as from Australia and the Pacific islands) is a relatively recent phenomenon. The Equisetum fossils add to a large group of plants that were present in New Zealand in the early-middle Miocene, became extinct there, but continued to exist on other landmasses. For example, various genera of conifers, Eucalyptus, Acacia and Casuarina are known from Miocene fossils of New Zealand but are absent from the extant flora (Mildenhall, 1980; Campbell and Holden, 1984; Pole, 1993b, 2007, 2012; Macphail et al., 1994). Equisetum also adds to a list of typical Mesozoic plant groups (e.g., cheirolepid conifers, Ginkgo, corystosperms and bennettitaleans) that survived the moderate rates of extinction at southern high-latitudes at the end of the Cretaceous (Pole and Vajda, 2009; Vajda and Bercovici, 2014) but disappeared from these regions some time during the Cenozoic (Carpenter and Hill, 1999; McLoughlin et al., 2008, 2011; Barreda et al., 2012).

The landmass that became New Zealand broke away from the Australian-Antarctic margin of Gondwana in the mid-Cretaceous. The notion of the Tasman Sea (or even the Pacific) as being an insurmountable barrier for plants has begun to change (Pole, 1994; Winkworth et al., 2002). Long-distance dispersal to New Zealand of plants that do not appear to have any long-distance dispersal ability appears to be a reality. Like ferns, Equisetum reproduces by spores. It is conceivable that the Miocene examples in New Zealand were a short-lived lineage of Equisetum that had dispersed to the South Island from outside the region in the mid-Cenozoic. However, given its earlier Mesozoic record, but current absence in the Australasian-Pacific region, it is perhaps most likely that the Miocene occurrences of this genus were relictual - and that New 

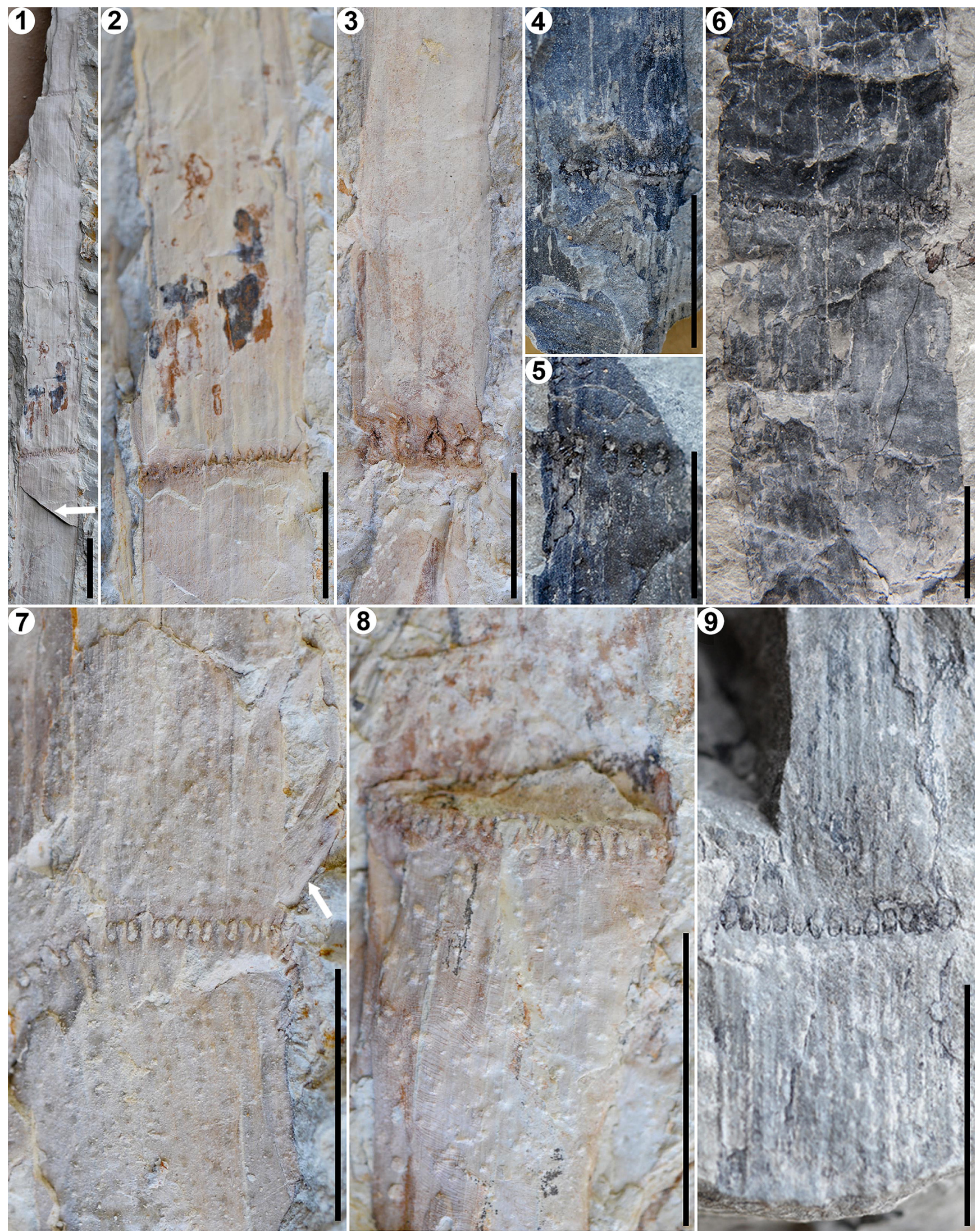

Fig. 2. Equisetum sp. fossils from Bannockburn (1-3, 7, 8) and Nuggety Creek near Murchison (4-6, 9), New Zealand. 1. LX837, slender axis consisting of pith cast (above arrow) and external impression (below arrow). 2. LX836, jointed axis external impression. 3. LX833, slender axis impression with ovate branch scars at node. 4. LX882, carbonaceous compression of jointed axis. 5. LX881, carbonaceous compression of jointed axis. 6. LX2065, carbonaceous compression of large jointed axis. 7. LX834, impression of exterio of axis with whorl of basally fused leaves (arrowed) above node. 8. LX834, impression of exterior of axis with numerous tightly spaced branch scars at node. 9. LX880, impression of exterior of jointed axis with well-defined ribbing. Scale bars: $10 \mathrm{~mm}(1-4,6-9), 5 \mathrm{~mm}(5)$. 
Zealand carried a compliment of Equisetum with it as it rafted into the Pacific in the Cretaceous. A closer look at the fossil record is likely to extend its record in New Zealand, and may well do so in Australia as well.

\subsection{Equisetalean extinction in Australasia}

A single cause for the demise of Equisetum in the New ZealandAustralian-Antarctic region is difficult to resolve. The rapid development of an extensive ice sheet over Antarctica around the Eocene-Oligocene transition (Coxall et al., 2005) may account for the loss of Equisetum on that continent, but New Zealand and Australia did not experience continental-scale glaciation. Australia, characterized by subdued topography and low-nutrient soils over much of its area, experienced stepwise warming and aridification, together with a dramatic change in its photoperiod regime as the continent shifted rapidly from high to middle and low southern latitudes through the mid-Cenozoic (Wilford and Brown, 1994). Concomitant vegetation changes saw the dramatic contraction of Nothofagus-dominated closed-forests and Proteaceae/Casuarinaceae-rich moist heathlands, and the expansion of Eucalyptus- and Acacia-dominated open sclerophyll forests and savanna (Hill et al., 1999). New Zealand has a complex Cenozoic history. By the early Paleocene, New Zealand had broken away from Australia via the south-to-north opening of the Tasman Sea. By the Eocene, New Zealand had moved to middle latitudes ( $40-50^{\circ}$ S; Veevers et al., 1991), i.e., at equivalent latitudes to northern Australia at that time. New Zealand supported a broadly similar flora to that of southern mainland Australia at that time in terms of taxonomic composition, leaf size and low proportion of conifers (Pole, 1993c). New Zealand remained at middle latitudes during Australia's rapid northward drift through the Miocene, but still experienced significant shifts in vegetation composition.

Pole (1993c, 2003) concluded that the current absence of Eucalyptus in New Zealand was the result of a wet phase following a middle Miocene relatively dry and fire-prone period - a scenario adopted by Hill et al. (2017). Low fire frequencies in the landscape, and the ensuing effects of an increase in closed-forest communities and changes in soil moisture and microbe/fungal associations later in the Neogene, may have all contributed to the decline of Eucalyptus in New Zealand. Modern Equisetum species thrive under a very broad range of conditions, being tolerant to disturbance, soil anoxia, high levels of metals, high salinity (Husby, 2013), at least low-intensity fire regimes (Ivanova et al., 2014), and they also have moderate levels of shade tolerance (Humbert et al., 2007). We cannot test directly whether a shift in the fire regime and the extent of closed-forest vegetation was relevant to the decline of Equisetum, but we note that, at least until the Miocene, New Zealand's vegetation ranged from various ?pure? rainforest types to some communities with a fire-induced sclerophyll component (Mildenhall and Pocknall, 1989; Pole, 1993c).

Through the late Neogene and Quaternary, the combined influences of New Zealand falling directly within the tracks of the mid-latitude westerly cyclones, rain shadow effects and sedimentation changes associated with the uplift of the Southern Alps, and cooling, drying and alpine glaciation associated with expansion of the polar ice sheets, wrought significant changes to the New Zealand flora (McGlone et al., 2001; Pole, 2003). In addition, extant Equisetum species appear to be vulnerable to competition from ruderal angiosperms, especially in areas with low soil moisture and/or high nitrogen (Husby, 2013). This combination of substantial environmental change (particularly drying and abrupt warming/cooling) and competition from diversifying angiosperm groups probably contributed to the demise of equisetaleans across the New Zealand-Australian-Antarctic region through the Cenozoic.

\section{Acknowledgements}

Financial supports to S.M. by the Swedish Research Council (VR grant 2014-5234) and National Science Foundation (project \#1636625) are gratefully acknowledged. M.S.P. appreciates the continued access to the Queensland Herbarium. We thank Prof. Robert Hill and Dr. Ignacio Escapa for their constructive comments on the manuscript.

\section{References}

Agardh, C., 1825. Classes Plantarum. Literis Berlingianis, Lund.

Arber, E.A.N., 1917. The earlier Mesozoic floras of New Zealand. New Zealand Geological Survey Bulletin 6, 1-80.

Barreda, V.D., Cúneo, N.R., Wilf, P., Currano, E.D., Scasso, R.A., Brinkhuis, H., 2012. Cretaceous/Paleogene floral turnover in Patagonia: drop in diversity, low extinction, and a Classopollis spike. PLoS ONE 7 (12), e52455.

Beattie, R., 2007. The geological setting and palaeoenvironmental and palaeoecological reconstructions of the Upper Permian insect beds at Belmont, New South Wales, Australia. African Invertebrates 48, 41-57.

Benson, L., 1957. Plant Classification. Heath, Boston.

von Berchtold, F.G., Presl, J.S., 1820. O prirozenosti Rostlin. Krala Wiljma Endersa, Prague.

Bold, H.C., Alexopoulos, C.J., Delevoryas, T., 1987. Morphology of Plants and Fungi, fifth ed. Harper Collins Publishers Inc.

Bomfleur, B., Escapa, I.H., Taylor, E.L., Taylor, T.N., 2013. A reappraisal of Neocalamites and Schizoneura (fossil Equisetales) based on material from the Triassic of East Antarctica. Alcheringa 37, 1-17.

Boureau, E., 1964. Traité de paléobotanique. Tome III. Sphenophyta, Noeggerathiophyta. Masson et Cie., Paris.

Brownsie, P.J., Perrie, L.R., 2015. Flora of New Zealand: Ferns and Lycophytes. Fascicle 6, Equisetaceae. Manaaki Whenua Press, Lincoln, N.Z. (Electronic resource: http://www.nzflora.info/pdfs/ FloraOfNewZealand-Ferns-6-BrownseyPerrie-2015-Equisetaceae. pdf. Accessed 5.12.2016).

Campbell, J.D., Holden, A.M., 1984. Miocene casuarinacean fossils from Southland and central Otago, New Zealand. New Zealand Journal of Botany 22, 159-167.

de Candolle, A.P., 1804. Essai sur les propriétés médicales des plantes, comparées avec leurs formes extérieures et leur classification naturelle. Didot Jeune, Paris.

Carpenter, R.J., Hill, R.S., 1999. Ginkgo leaves from Paleogene sediments in Tasmania. Australian Journal of Botany 47, 717-724.

Channing, A., Zamuner, A., Edwards, D., Guido, D., 2011. Equisetum thermale sp. nov. (Equisetales) from the Jurassic San Agustín hot spring deposit, Patagonia: anatomy, paleoecology, and inferred paleoecophysiology. American Journal of Botany 98, 680-697.

Clifford, H.T., Constantine, J., 1980. Ferns, Fern Allies and Conifers of Australia. University of Queensland Press, St Lucia.

Coiffard, C., Gomez, B., Thévenard, F., 2007. Early Cretaceous angiosperm invasion of western Europe and major environmental changes. Annals of Botany 100, 545553.

Cooper, R.A. (Compiler), 2004. New Zealand Geological Timescale 2004/2 wallchart. Institute of Geological and Nuclear Sciences information series 64.

Coxall, H.K., Wilson, P.A., Pälike, H., Lear, C.H., Backman, J., 2005. Rapid stepwise onset of Antarctic glaciation and deeper calcite compensation in the Pacific Ocean. Nature 433, 53-57

Daniel, I.L., 1989. Taxonomic Investigation of Elements from the Early Cretaceous Megaflora from the Middle Clarence Valley, New Zealand (Ph.D. Dissertation). University of Canterbury (unpubl.).

Daniel, I.A., Lovis, J.D., Reay, M.B., 1990. A brief introductory report on the midCretaceous megaflora of the Clarence Valley, New Zealand. In: Douglas, J.G., Christophel, D.C. (Eds.), Proceedings of the 3rd International Organization of Palaeobotany Conference, Melbourne, 1988. A-Z Printers, Melbourne, pp. 2729.

Des Marais, D.L., Smith, A.R., Britton, D.M., Pryer, K.M., 2003. Phylogenetic relationships and evolution of extant horsetails, Equisetum, based on chloroplast DNA sequence data $(r b c L$ and $\operatorname{trn} L-F)$. International Journal of Plant Sciences $164,737-751$

Douglas, B.J., 1986. Lignite resources of Central Otago. New Zealand Energy Research and Development Committee Publication P104, 367.

Douglas, J.G., 1973. The Mesozoic floras of Victoria. Part 3. Memoirs Geological Survey of Victoria 29, 1-185.

Edwards, W.N., 1934. Jurassic plants from New Zealand. Annals and Magazine of Natural History 10, 81-109.

Elgorriaga, A., Escapa, I.H., Bomfleur, B., Cúneo, R., Ottone, E.G., 2015. Reconstruction and phylogenetic significance of a new Equisetum Linnaeus species from the Lower Jurassic of Cerro Bayo (Chubut Province, Argentina). Ameghiniana 52, $135-152$.

von Ettingshausen, C., 1891. Contributions to the knowledge of the fossil flora of New Zealand. Transactions of the New Zealand Institute 23, 237-310.

Falcon-Lang, H.J., Cantrill, D.J., Nichols, G.J., 2001. Biodiversity and terrestrial ecology of a mid-Cretaceous, high-latitude floodplain, Alexander Island, Antarctica. Journal of the Geological Society of London 158, 709-724. 
Fyfe, H.E., 1968. Geology of Murchison Subdivision. New Zealand Geological Survey Bulletin n.s. 36, 1-51.

Gee, C.T., 1989. Revision of the Late Jurassic/Early Cretaceous flora from Hope Bay, Antarctica. Palaeontographica Abt. B 213, 149-214.

Gould, R.E., 1968. Morphology of Equisetum laterale Phillips, 1829, and E. bryanii sp. nov. from the Mesozoic of southeastern Queensland. Australian Journal of Botany 16, 153-176.

Guillon, J.-M., 2004. Phylogeny of horsetails (Equisetum) based on the chloroplast rps4 gene and adjacent noncoding sequences. Systematic Botany 29, 251-259.

Guillon, J.-M., 2007. Molecular phylogeny of horsetails (Equisetum) including chloroplast atpB sequences. Journal of Plant Research 120, 569-574.

Gutiérrez, P.R., 1995. Nuevos registros paleoflorísticos para la Formación Agua Colorada, Carbonífero Superior, en el sector sudoriental de la Sierra de Famatina, provincial de La Rioja, Argentina. Ameghiniana 32, 111-128.

Harris, T.M., 1961. The Yorkshire Jurassic Flora. I. Thallophyta-Pteridophyta. British Museum (Natural History), London.

Hauke, R.L., 1963. A taxonomical monograph of the genus Equisetum subgenus Hippochaete. Beheifte zur Nova Hedwigia 8, 1-123.

Hauke, R.L., 1978. A taxonomic monograph of Equisetum subgenus Equisetum. Nova Hedwigia 30, 385-455.

Hauke, R.L., 1990. Equisetaceae. In: Kramer, K.U., Green, P.S. (Eds.), The Families and Genera of Vascular Plants. Pteridophytes and Gymnosperms. Springer-Verlag, Berlin, pp. 46-48.

Hauke, R.L., 1993. Equisetaceae Michaux ex DeCandolle. In: Argus, G.W., et al. (Eds.), Flora of North America, Volume 2. Pteridophytes and Gymnosperms. Oxford University Press, Oxford, pp. 64-75.

Hill, R.S., Truswell, E.M., McLoughlin, S., Dettmann, M.E., 1999. The evolution of the Australian flora: fossil evidence. In: Orchard, A.E. (Ed.), Flora of Australia, 2nd edition, 1 (Introduction). ABRS/CSIRO, Collingwood, pp. 251-320.

Hill, R.S., Beer, Y.K., Hill, K.E., Maciunas, E., Myall, A., Tarran, M.A., Wainman, C.C., 2017. Evolution of the eucalypts - an interpretation from the macrofossil record. Australian Journal of Botany 64 , http://dx.doi.org/10.1071/BT16117.

Holden, A.M., 1982a. Fossil Nothofagus from the Longford Formation, Murchison, New Zealand. Journal of the Royal Society of New Zealand 12, 65-77.

Holden, A.M., 1982b. Fossil Lauraceae and Proteaceae from the Longford Formation, Murchison, New Zealand. Journal of the Royal Society of New Zealand 12, 7980.

Holmes, W.B.K., 2001. Equisetalean plant remains from the Early to Middle Triassic of New South Wales, Australia. Records of the Australian Museum 531, 9-20.

Humbert, L., Gagnon, D., Kneeshaw, D., Messier, C., 2007. A shade tolerance index for common understory species of northeastern North America. Ecological Indicators 7, 195-207.

Husby, C., 2013. Biology and functional ecology of Equisetum with emphasis on the giant horsetails. Botanical Review 79, 147-177.

Ivanova, A.A., Kopylova-Guskova, E.O., Shipunov, A.B., Polina, A., Volkova, P.A., 2014. Post-fire succession in the northern pine forest in Russia: a case study. Wulfenia $21,119-128$.

Kenrick, P., Crane, P.R., 1997. The Origin and Early Diversification of Land Plants: A Cladistic Study. Smithsonian Institution Press, Washington.

Labandeira, C.C., 2013. A paleobiologic perspective on plant-insect interactions. Current Opinion in Plant Biology 16, 414-421.

Lihou, J.C., 1993. The structure and deformation of the Murchison Basin, South Island, New Zealand. New Zealand Journal of Geology and Geophysics 36, 95105.

von Linnaeus, C., 1753. Species plantarum, exhibentes plantasrite cognitas, ad genera relatas, cum differentiis specificis, nominibus trivialibus, synonymis selectis, locis natalibus, secundum systema sexuale digestas. L. Salvii, Holmiae.

Macphail, M.K., Alley, N.F., Truswell, E.M., Sluiter, I.R.K., 1994. Early Tertiary vegetation: Evidence from spores and pollen. In: Hill, R.S. (Ed.), History of the Australian Vegetation: Cretaceous to Recent. Cambridge University Press, Cambridge, pp. 189-261.

McGlone, M.S., Duncan, R.P., Heenan, P.B., 2001. Endemism, species selection and the origin and distribution of the vascular plant flora of New Zealand. Journal of Biogeography 28, 199-216.

McLoughlin, S., 1992a. Late Permian plant megafossils from the Bowen Basin, Queensland, Australia: part 1. Palaeontographica Abt. B 228, 105-149.

McLoughlin, S., 1992b. Permian sphenophytes from the Collie and Perth basins, Western Australia. Review of Palaeobotany and Palynology 75, 153-182.

McLoughlin, S., Drinnan, A.N., 1995. A Middle Jurassic flora from the Walloon Coal Measures, Mutdapilly, Queensland, Australia. Memoirs of the Queensland Museum 38, 257-272.

McLoughlin, S., Tosolini, A.-M.P., Drinnan, A.N., 2000. Revision of an Early Cretaceous macroflora from the Maryborough Formation, Maryborough Basin, Queensland, Australia. Memoirs of the Queensland Museum 45, 483-503.

McLoughlin, S., Tosolini, A.-M., Nagalingum, N., Drinnan, A.N., 2002. The Early Cretaceous (Neocomian) flora and fauna of the lower Strzelecki Group, Gippsland basin, Victoria, Australia. Association of Australasian Palaeontologists Memoir 26, 1-144.

McLoughlin, S., Carpenter, R.J., Jordan, G.J., Hill, R.S., 2008. Seed-ferns survived the end-Cretaceous mass extinction in Tasmania. American Journal of Botany 95, 465-471.

McLoughlin, S., Pott, C., Elliott, D., 2010. The Winton Formation flora (AlbianCenomanian, Eromanga Basin): implications for vascular plant diversification and decline in the Australian Cretaceous. Alcheringa 34, 303-323.
McLoughlin, S., Carpenter, R.J., Pott, C., 2011. Ptilophyllum muelleri (Ettingsh.) comb. nov, from the Oligocene of Australia: last of the Bennettitales? International Journal of Plant Sciences 172, 574-585.

McQueen, D.R., 1954. Upper Palaeozoic plant fossils from South Island, New Zealand. Transactions of the Royal Society of New Zealand 82, 231-236.

Mildenhall, D.C., 1980. New Zealand Late Cretaceous and Cainozoic plant biogeography: a contribution. Palaeogeography, Palaeoclimatology, Palaeoecology 31 , 197-233.

Mildenhall, D.C., Pocknall, D.T., 1989. Miocene-Pleistocene spores and pollen from central Otago, South Island, New Zealand. New Zealand Geological Survey Palaeontological Bulletin 59, 1-128.

Morris, N., 1985. The floral succession in eastern Australia. In: Dias, C.M. (Ed.), The Carboniferous of the World, v. 2. Instituto Geologico y Mineras de Espana, Madrid, pp. 118-123.

Nathan, S., Anderson, H.J., Cook, R.A., Herzer, R.H., Hoskins, R.H., Raine, J.I., Smale, D. 1986. Cretaceous and Cenozoic sedimentary basins of the West Coast Region, South Island, New Zealand. New Zealand Geological Survey basin studies 1, 189.

Osborn, J.M., Phipps, C.J., Taylor, T.N., Taylor, E.L., 2000. Structurally preserved sphenophytes from the Triassic of Antarctica: reproductive remains of Spaciinodum. Review of Palaeobotany and Palynology 111, 225-235.

Parrish, J.T., Daniel, I.L., Kennedy, E.M., Spicer, R.A., 1998. Paleoclimatic significance of mid-Cretaceous floras from the middle Clarence Valley, New Zealand. Palaios $13,149-159$.

Pole, M.S., 1993a. Early Miocene flora of the Manuherikia Group, New Zealand. 10. Paleoecology and stratigraphy. Journal of the Royal Society of New Zealand 23, 393-426.

Pole, M.S., 1993b. Early Miocene floras of the Manuherikia Group, New Zealand. 7. Myrtaceae, including Eucalyptus. Journal of the Royal Society of New Zealand 23, 313-328.

Pole, M., 1993c. Keeping in touch: vegetation prehistory on both sides of the Tasman. Australian Systematic Botany 6, 387-397.

Pole, M., 1994. The New Zealand flora - entirely long-distance dispersal? Journal of Biogeography 21, 625-635.

Pole, M., 2003. New Zealand climate in the Neogene and implications for global atmospheric circulation. Palaeogeography, Palaeoclimatology, Palaeoecology 193, 269-284.

Pole, M., 2007. Conifer and cycad distribution in the Miocene of southern New Zealand. Australian Journal of Botany 55, 143-164.

Pole, M., 2012. Chapter 26-Plant macrofossils. In: Gordon, D.P. (Ed.), New Zealand Inventory of Biodiversity, v. 3. Canterbury University Press, Christchurch, pp. 460-475.

Pole, M., Vajda, V., 2009. A new terrestrial Cretaceous-Paleogene site in New Zealand - turnover in macroflora confirmed by palynology. Cretaceous Research 30, 917-938.

Pryer, K.M., Schneider, H., Smith, A.R., Cranfill, R.P., Wolf, G., Hunt, J.S., Sipes, S.D., 2001. Horsetails and ferns are a monophyletic group and the closest living relatives to seed plants. Nature 409, 618-621.

Pryer, K.M., Schuettpelz, E., Wolf, P.G., Schneider, H., Smith, A.R., Cranfill, R., 2004. Phylogeny and evolution of ferns (monilophytes) with a focus on the early leptosporangiate divergences. American Journal of Botany 91, 1582-1598.

Rees, P.M., Cleal, C.J., 2004. Lower Jurassic floras from Hope Bay and Botany Bay, Antarctica. Special Papers in Palaeontology 72, 1-90.

Retallack, G.J., 1980. Middle Triassic megafossil plants and trace fossils from Tank Gully, Canterbury, New Zealand. Journal of the Royal Society of New Zealand 10 31-63.

Retallack, G.J., 1985. Triassic fossil plant fragments from shallow marine rocks of the Murihiku Supergroup, New Zealand. Journal of the Royal Society of New Zealand 15, 1-26.

Retallack, G.J., 1999. Carboniferous fossil plants and soils of an early tundra ecosystem. Palaios 14, 324-336.

Rigby, J.F., 1966. Some Lower Gondwana articulates from New South Wales. In: Surange, K.R. (Ed.), Symposium on Floristics and Stratigraphy of Gondwanaland. Birbal Sahni Institute of Palaeobotany, Lucknow, pp. 48-54.

Rigby, J.F., 1969. Permian sphenopsids from Antarctica. Geological Survey Professional Paper 613F, 1-12.

Rössler, R., Noll, R., 2002. Der permische versteinerte Wald von Araguaina/Brasilien: Geologie, Taphonomie und Fossilführung. Veröffentlichungen des Museums für Naturkunde Chemnitz 25, 5-44.

Rössler, R., Noll, R., 2006. Sphenopsids of the Permian (I): the largest known anatomically preserved calamite, an exceptional find from the petrified forest of Chemnitz, Germany. Review of Palaeobotany and Palynology 140, 145-162.

Scott, D.H., 1900. Studies in Fossil Botany, first ed. A\&C Black, London.

Smith, A.R., Pryer, K.M., Schuettpelz, E., Korall, P., Schneider, H., Wolf, P.G., 2006. A classification for extant ferns. Taxon 55, 705-731.

Smith, G.M., 1955. Cryptogamic Botany, Volume 2: Bryophytes and Pteridophytes. McGraw-Hill, New York and London.

Taylor, T.N., Taylor, E.L., Krings, M., 2009. Paleobotany - The Biology and Evolution of Fossil Plants. Academic Press, Burlington1230.

Tucker, R.T., Roberts, E.M., Hu, Y., Kemp, A.I.S., Salisbury, S.W., 2013. Detrital zircon age constraints for the Winton Formation, Queensland: contextualizing Australia's Late Cretaceous dinosaur faunas. Gondwana Research 24, 767-779.

Turner, S., Bean, L.B., Dettmann, M., McKellar, J., McLoughlin, S., Thulborn, T., 2009. Australian Jurassic sedimentary and fossil successions: current work and future prospects for marine and non-marine correlation. GFF 131, 49-70. 
Vajda, V., Bercovici, A., 2014. The global vegetation pattern across the CretaceousPaleogene mass extinction interval: a template for other extinction events. Global and Planetary Change 122, 29-49.

Veevers, J.J., Powell, C.Mc.A., Roots, S.R., 1991. Review of seafloor spreading around Australia. I. Synthesis of the patterns of spreading. Australian Journal of Earth Sciences 38, 373-389.

Wilford, G.E., Brown, P.J., 1994. Maps of late Mesozoic-Cenozoic Gondwana breakup: some paleogeographical implications. In: Hill, R.S. (Ed.), History of the
Australian Vegetation. Cretaceous to Recent Cambridge University Press, Cambridge, pp. 5-13.

Winkworth, R.C., Wagstaff, S.J., Glenny, D., Lockhart, P.J., 2002. Plant dispersal N.E.W.S. from New Zealand. Trends in Ecology and Evolution 17, 514-520. Zittel, K.A., 1879-1890. Handbuch der Paläontologie. Druck und Verlag von R. Oldenbourg, Munich and Leipzig. 